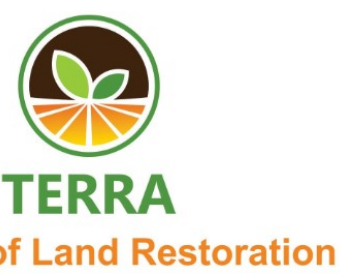

\title{
Mapping Location of The Former Land of The Unlicensed Gold Mining (Ugm) in A Several Subdistricts in Kuantan Singingi District
}

\author{
Sri Mulyani ${ }^{1}$, Raisa Baharuddin ${ }^{1}$, Defri Kurnia Putra Sidiq ${ }^{1}$, Anandyawati Anandyawati ${ }^{2}$ \\ ${ }^{1}$ Agrotechnology Department, Islamic University of Riau \\ ${ }^{2}$ Soil Science Department, University of Bengkulu (Corresponding author) \\ e-mail:anandyawati@unib.ac.id
}

\begin{abstract}
Public gold mining carried out without permission and not organized is rife in Riau. Until now there is still lack of information about Unlicensed Gold Mining (UGM) in Kuantan Singingi District specifically Singingi subdistrict, Kuatan Tengah, Sentajo Raya, and Logas Tanah Darat. The former gold mining land cannot be used for agricultural activities. To overcome this problem reclamation needs to be done on the former gold mine land. However, before the step is taken, the initial step is mapping the point of the location of the former gold mine, general conditions, land ownership status and mining processes, vegetation in UGM land and the impact of UGM in Singingi subdistrict, Kuatan Tengah, Sentajo Raya, and Tanah Darat Logas. This study aims to map the distribution of the land of the former gold mine, determine general conditions, land ownership status and mining processes, the vegetation of former UGM land and the impact of UGM in Singingi District, Central Kuatan, Sentajo Raya and Tanah Darat Logas, in Kuantan Singingi District. The parameters observed were: point of distribution of the location of the former gold mine, general conditions, land ownership status, and the mining process, vegetation of former UGM land, and the impact of UGM. The results showed that in all subdistricts sample namely Singingi, Kuatan Tengah, Sentajo Raya, and Tanah Darat Logas in Kuantan Singingi District there were unlicensed gold mining along the river flow area. Overall land ownership status is owned by individuals/individuals (people with capital) and land used for mining activities that are owned by others rent. There are three types of species that grow on the former gold mine land that is Melastoma malabathricum L., Cyperus halpan L., and Scleria sumatrensis Retz. While the real impact of unlicensed gold mining activities is the loss of river water bodies.
\end{abstract}

Keywords: mapping, PETI and Kuantan Singingi

\section{INTRODUCTION}

Definition of Unlicensed Gold Mining (UGM) is a mining business carried out by an individual, group of people, or a legal entity foundation company that is in operation does not have a permit from the government following the regulations requested. Unlicensed Gold Mining (UGM ) was caused by the existence of traditional miners, who developed because of poverty, limited employment, and business opportunities.

The Public's gold mining carried out without permission and not organized is rife in Riau. Until now there is still a lack of information about Unlicensed Gold Mining (UGM) in Kuantan Singingi District, especially Singingi subdistrict.

TERRA,3(1), 27-31 (2020)
But based on BPS (2011) that there are around $2.6 \%$ of the population aged 15 years and over who work in mining and quarrying, then in 2017 there were criminal reports on Unlicensed Gold Mining (UGM) in Kuantan Singingi District totaling 45 people who were reported to the Polres/Polresta. Based on the results of a preliminary survey on 18 February 2018 that in the field found the land of a former gold mine in the subdistrict of Singingi, Kuatan Tengah, Sentajo Raya, and Logas Tanah Darae. This is a reference for the place of research.

UGM will have a bad impact on the environment around the mining area, such as damage to the land/land of former mining activities. According to Nuraini et al., (2014), gold mining activities hurt the formation of critical land in the form of exgold mining land that cannot function properly in 
supporting plant growth. Seeing the negative impacts arising from mining activities on land that is managed by the community and the state, it is necessary to take special care to address land damage so that it does not get worse and can cause natural disasters that harm the local environment, namely by efforts to rehabilitate the land. Land rehabilitation activities include reclamation activities, which are efforts to repair damaged land as a result of mining activities so that they can function optimally according to their abilities, which are then followed by revegetation activities, where revegetation activities are replanting activities in damaged forest areas. After that, an evaluation of the reclamation and revegetation activities will be carried out so that the level of success can be known (Putra, 2010).

According to Juniarti et al. (2013), before the reclamation and revegetation activities, the first step that needs to be taken is mapping the former mining land, which is completed with the status of ownership or land tenure, so that the subsequent use both for agriculture and other businesses can be sustainable. The purpose of this research is to map the distribution of the land of the former gold mine in Singingi subdistrict, Kuatan Tengah subdistrict, Sentajo Raya subdistrict and Logas Tanah Darat subdistrict in Kuantan Singingi district and to find out the general condition, the status of land ownership and the mining process, the vegetation of the former UGM land and the impact of Unlicensed Gold Mining (UGM) in Singingi subdistrict, Kuatan Tengah subdistrict, Sentajo Raya subdistrict and Logas Tanah Darat subdistrict in Kuantan Singingi

\section{MATERIAL AND METHOD}

This research was conducted in four subdistricts namely Singingi subdistrict, Kuatan Tengah subdistrict, Sentajo Raya subdistrict, and Logas Tanah Darat subdistrict. This research was carried out for 3 months starting from August to October 2018.

The tools used in this study are machetes, GPS (Global Position System) Garmin GPSmap 76CS x, Base Camp_470 software, ArcGIS 10 software, Kuantan Singingi District administrative map scale 1: 50,000, district river network map Kuantan Singingi 1: 50.000 scale, stationery, and digital camera.

In this study the method used for data collection is explained as follows:

\section{Observation Method}

Observation is direct observation through the activities of focusing attention on an object by using the senses. Researchers observed the location of a former land of the Unlicensed Gold Mining (UGM) using the GPS (Global Position System) Garmin GPSmap 76CS x.

\section{Interview Method}

The interview is a dialogue conducted by the interviewer to obtain information from the interviewer. Interviews were conducted with local communities around a former land of the Unlicensed Gold Mining (UGM).

\section{Documentation Method}

The documentation method is a way to collect data through written relics, especially several archives, and also includes books on theoretical opinions, drawings, maps, and others related to research problems, namely on the former land of the Unlicensed Gold Mining (UGM).

Data analysis in this study uses spatial analysis, descriptive explanation without statistical tests. The data obtained are presented in the form of tables and figures.

\section{RESULT AND DISCUSSION}

Map of Location a Former Land of the Unlicensed Gold Mining (UGM) in Several Subistricts in Kuansing District

Surveys and interviews were conducted in four subdistricts namely, Singingi subdistrict, Kuantan Tengah subdistrict, Sentajo Raya subdistrict, and Logas Tanah Darat subdistrict. Based on survey results and direct interviews, several Unlicensed Gold Mining (UGM) points were found in the four sample subdistricts (Table 1).

Table 1. The Coordinate Point of Location a Former Land of the Unlicensed Gold Mining (UGM) in Several Subistricts in Kuansing District

\begin{tabular}{|c|c|c|}
\hline \multirow{2}{*}{ Number of Location } & \multicolumn{2}{|c|}{ Coordinate Point } \\
\cline { 2 - 3 } & East Longitude & South Latitude \\
\hline 667 & $101^{\circ} 23^{\prime} 55^{\prime \prime}$ & $0^{\circ} 28^{\prime} 11^{\prime \prime}$ \\
\hline 669 & $101^{\circ} 29^{\prime} 36^{\prime \prime}$ & $0^{\circ} 19^{\prime} 26^{\prime \prime}$ \\
\hline 671 & $101^{\circ} 33^{\prime} 18^{\prime \prime}$ & $0^{\circ} 18^{\prime} 36^{\prime \prime}$ \\
\hline 673 & $101^{\circ} 29^{\prime} 49^{\prime \prime}$ & $0^{\circ} 25^{\prime} 27^{\prime \prime}$ \\
\hline 677 & $101^{\circ} 28^{\prime} 11^{\prime \prime}$ & $0^{\circ} 24^{\prime} 58^{\prime \prime}$ \\
\hline
\end{tabular}

The distribution of a former land of the Unlicensed Gold Mining (UGM) in the four subdistricts of Kuantan District is entirely in the watershed (Figure 1). In Singingi District, two former a former land of the Unlicensed Gold Mining (UGM) locations were found, namely No. 667 and No. 677 located in the Batang Lambukerun river basin and the Batang Tengkalakgedang river basin. 


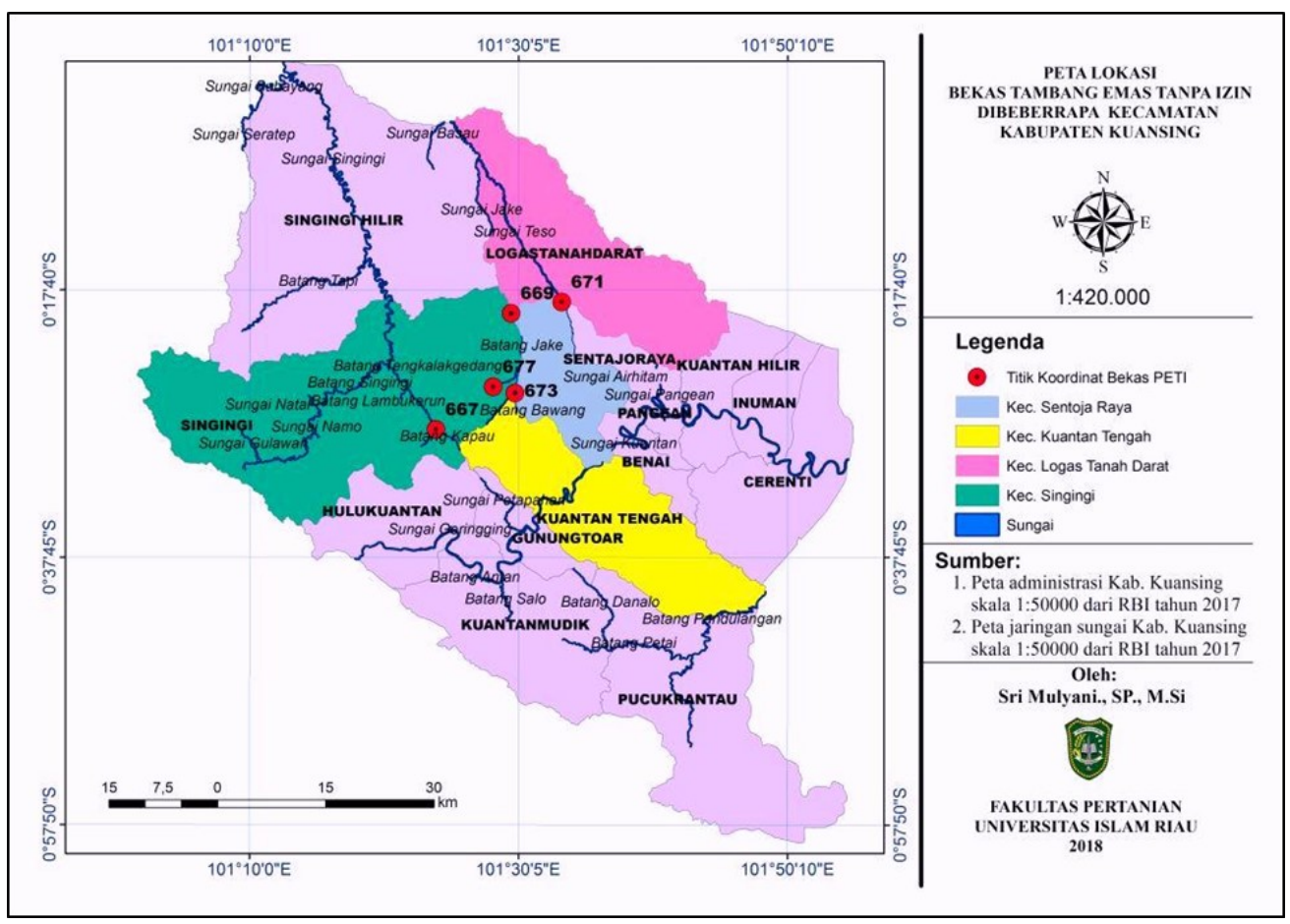

Figure 1. Map of the location a former land of the Unlicensed Gold Mining (UGM) in several subdistricts in Kuantan Singingi District

In Kuantan Tengah subdistrict (No. 673) it is found in the Jake River flow. In the Sentoja Raya subdistrict (No. 699) it was found in the Jake river flow. And in the Logas Tanah Darat subdistrict (No. 671) found in the Teso river. Results are the same with the study was conducted by Yulianti et al. (2016) that Unlicensed Gold Mining (UGM) was carried out along the Limun River flow in Limun subdistrict, Sarolangun district, Jambi Province. Added from the research results of Sakina et al. (2017), Unlicensed Gold Mining (UGM) in Sumbawa district is mostly done near water sources.

\section{General Social Conditions}

Astronomically, Kuantan Singingi district is located between 0000 - 1000 south latitude and 101002 - 101055 east longitude. Kuantan Singingi consists of 15 subdistricts among others Kuantan Mudik, Hulu Kuantan, Gunung Toar, Rantau Pucuk, Singingi, Singingi Hilir, Kuantan Tengah, Sentajo Raya, Benai, Kuantan Hilir, Pangean, Land Logas, Kuantan Hilir Seberang, Cerenti and Inuman. And the sample subdistricts are Singingi, Kuatan Tengah, Sentajo Raya and Logas Tanah Darat.

Based on its geographical position, Kuantan Singingi district has boundaries: in the north it bor- ders Kampar district and Pelalawan district, in the south it borders Jambi Province, in the west, it borders West Sumatra Province and in the east it borders Indragiri Hulu district. The area of Kuantan Singingi district is $7,656.03 \mathrm{~km}^{2}$, with 15 subdistricts and 229 villages. The population in Kuantan Singingi district is 321,216 people, divided into 164,769 men and 156,447 women (BPS, 2018).

\section{Land Ownership Status and Processing Process of Unlicensed Gold Mining}

The system of ownership of unlicensed gold mining activities in Singingi subdistrict, Kuatan Tengah, Sentajo Raya, and Logas Tanah Darat is entirely owned by individuals/individuals (capitals) and land that is used for mining activities owned by others/ leases along river basins.

Based on direct interviews with the community and findings on the ground that unlicensed gold mining activities are carried out along river basins. This was done to facilitate the activities of the miners in the process of finding gold. River water is used to spray the ground on an average using a $5.5 \mathrm{PK} /$ unit to mine gold, then the material is processed into a "sluice box" which is then heavy minerals left in the sluice box in the tray to obtain gold. 


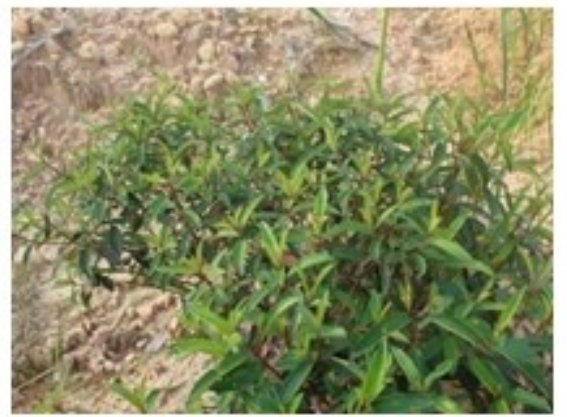

Figure 2.Melastoma malabathricum $\mathrm{L}$.

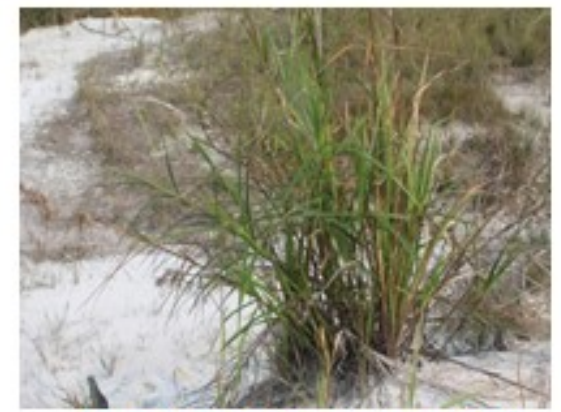

Figur 3. Sclevia sumatrensis Retz

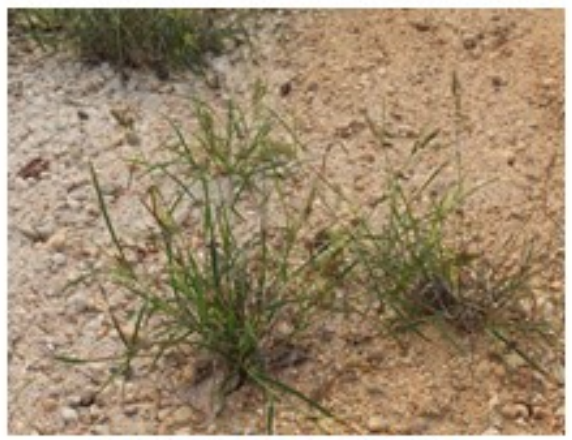

Figur 4.Cyperus halpan L.

Vegetation in a former land of the Unlicensed Gold Mining (UGM)

Vegetation is a group/collection of plant communities consisting of several types that live together in a place and interact with each other (Ardhana, 2012). Basic vegetation is a layer of ground cover plants consisting of herbs, shrubs, lianas, and ferns. In the ruined habitat also found basic vegetation as a pioneer plant. This can also occur in former mines (Nursyahra, 2016).

There are three types of plants found in a former land of the Unlicensed Gold Mining (UGM) in Singingi subdistrict, Kuatan Tengah subdistrict, Sentajo Raya subdistrict and Logas Tanah Darat subdistrict, which is: Melastoma malabathricum L species. (Melastomaceae), Cyperus halpan L. (Cyiperaceae), and Scleria sumatrensis Retz (Cyiperaceae). The three species were also found in the results of Nursyahra (2016) research at the site of the former gold mining in Nagari Gunung Medan, Sitiung subdistrict, Dharmasraya district. Then the same thing from the results of research Lestari et al. (2009) about the analysis of vegetation in the land of former mining land in the village of Rebo Bangko district obtained a dominant plant found as basic vegetation is Melastoma malabatricum. According to Heddy (2012) mentions vegetation is a reflection of the interaction of various environmental factors with living things.

\section{The Impact Unlicensed Gold Mining (UGM)}

The publication of unlicensed gold mining in Kuantan Singingi district has not existed yet. Yet based on direct interviews and findings in the field of mining activities have long been carried out since 10 years ago. But if it refers to the publication of BPS Kuantan Singingi district (2018) regarding the number of crimes that occurred in the Kuantan Singingi District police jurisdiction in 2017 in the case of unlicensed mining totaling 45 people. This means that unlicensed gold mining is in Kuantan Singingi district.

Kristanto (2004) explains the impact is any change that occurs in the environment due to human activity. Sodikin (2007) environmental damage is an environmental setback that is accompanied by the loss of natural resources, water, air, extinction of wild fauna, and damage to ecosystems. According to Soeprapto (2012), humans are the main cause of environmental damage (ecosystems). This is in line with the increasing human population in the world so that doing things that can damage the environment in the ecosystem. Such as unlicensed gold mining is rife in the 4 sub-districts of Kuantan Singingi district, namely Singingi subdistrict, Kuatan Tengah subdistrict, Sentajo Raya subdistrict, and Logas Tanah Darat subdistrict.

The main cause of Unlicensed Gold Mining (UGM) based on field findings is siltation in water 
bodies/siltation of rivers (Figure 5). This is consistent with the results of the study of Yulianti et al., (2016) that the impact of unlicensed gold mining (UGM) waste on the water quality of the river Limun Sarolangun district of Jambi province can occur siltation on the water body when suspended solid is calm at the bottom of the water body.

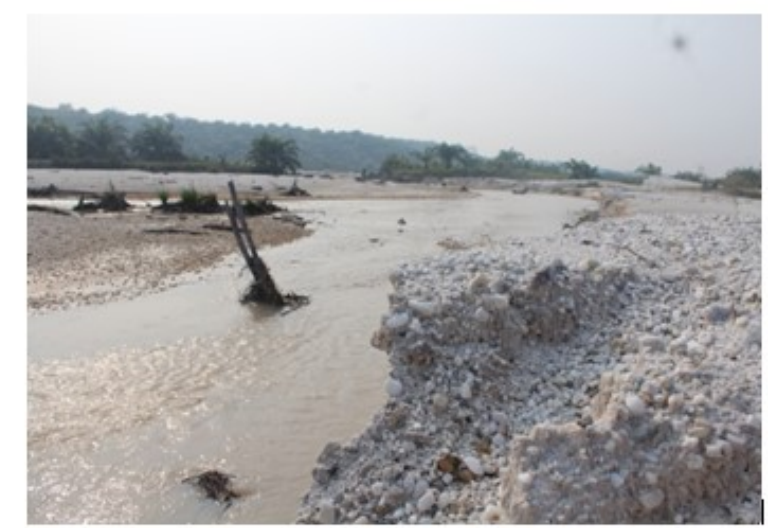

Figure 5. Siltation of river water impacts from Unlicensed Gold Mining (UGM)

\section{CONCLUSION}

Based on the results of the study with the title Mapping Location of the Former Land of the Unlicensed Gold Mining (UGM) in Several subdistricts in Kuantan Singingi District, the following conclusions were obtained: (1). Singingi subdistrict, Kuatan Tengah subdistrict, Sentajo Raya, and Logas Tanah Darat subdistrict in Kuantan Singingi district, there are unlicensed gold mining along the river flow area; (2). The overall land ownership status is owned by individuals or capitals individuals and land used for mining activities owned by others or leases along the watershed; (3). There are three types of species that grow in former mining areas, namely Melastoma malabathricum L., Cyperus halpan L., and Scleria sumatrensis Retz.; (4). The real impact of unlicensed gold mining activities is the loss of river water bodies.

\section{References}

Ardhana, I.P.G. (2012). Ekologi Tumbuhan. Udayana University Press., Denpasar.

[BPS] Badan Pusat Statistik. (2018). Kuantan Singingi Dalam Angka 2017. Taluk Kuantan.

[BPS] Badan Pusat Statistik. (2011). Riau Dalam Angka 2010. Pekanbaru.
Heddy, S. (2012). Metode Analisis Vegetasi dan Komunitas. PT RajaGrafindo Persada, Jakarta.

Juniarti, U. S., Sidabutar, J. \& , Anwar, C.S. (2013). Perubahan karakteristik kimia tanah pada model reklamasi lahan bekas tambang PT. Antam UBPE Pongkor. Jurnal Silvikultur Tropika, (4), 141-149.

Kristanto P. (2004). Ekologi Industri. ANDI, Yogyakarta.

Lestari, T., Abdi, Z., Widodo, J. \& Yohanes. (2009). Analisis vegetasi di lahan bekas penambangan timah Desa Rebo Ke. Bangka. Emiagro, Jurnal Pertanian. 2(2), 11-28.

Nuraini, Linda, R \& Gusrizal. (2014). Pengkayaan tanah bekas tambang emas dengan penambahan lumpur IPAM sebagai media pertumbuhan sawi (Brassica juncea L.). Jurnal Protobiont, 3(2), 135-140.

Nursyahra. (2016). Kepadatan vegetasi dasar pada lokasi bekas penambangan emas di Nagari Gunung Medan Kecamatan Sitiung Kabupaten Dharmasraya. BioCONCETTA: Jurnal Biologi dan Pendidikan Biologi. 2(1), 81-88. DOI: 10.22202/bc.2016.v2i1.1488.

Putra, C.A.S. (2010). Evaluasi Revegetasi Lahan Bekas Tambang EmasPT. Newmont Minahasa Raya,Manado, Sulawesi Utara. Departemen Silvikultur, Fakultas Kehutanan Institut Pertanian Bogor, Bogor.

Sakinah. A, Salahudin \& Yumitro, G. (2017). Upaya Dinas Lingkungan Hidup dalam Pengendalian dan Kerusakan Lingkungan Akibat Pertambangan Emas Tanpa Izin di Kabupaten Sumbawa. Jurusan Ilmu Pemerintahan Universitas Muhammadiyah Malang.

Sodikin. (2007). Penegakan Hukum Lingkungan Tinjauan atas Undang-Undang Nomor 23 Tahun 1997. Djambatan, Jakarta.

Suprapto, S.J. (2012). Makalah Tinjauan Reklamasi Lahan Bekas Tambang dan Aspek Konservasi Bahan Galian.Kelompok Program Penelitian Konsevasi. Makalah. Pusat Sumber Daya Geologi.

Yulianti. R, Sukiyah. E \& Sulaksana. N. (2016). Dampak limbah penambangan emas tanpa izin (PETI) terhadap kualitas air Sungai Limun Kabupaten Sarolangun Propinsi Jambi. Bulletin of Scientific Contribution. Fakultas Teknik Geologi, Universitas Padjadjaran. 14(3). 251-262. DOI: 10.24198/bsc.vol14.yr2016.art1 0969 